\title{
PEMBERIAN ROM PASIF TERHADAP HEMODINAMIKA PASIEN POST OPERASI DI RUANG RAWAT INAP RSUD BANYUMAS
}

\author{
Siti Usfatun Khasanah'1, Mustiah Yulistiani² \\ Fakultas Ilmu Kesehatan Program Studi Sarjana Keperawatan Universitas \\ Muhammadiyah Purwokerto \\ Jl. Raya Dukuh Waluh, PO BOX 202, Purwokerto 53182, Kembaran Banyumas, Indonesia \\ sukhasanah0@gmail.com
}

\begin{abstract}
Abstrak
Operasi mengakibatkan terputusnya kontinuitas jaringan tubuh. Pasien post operasi diperlukan monitoring hemodinamik guna menunjang kesehatannya. Mengetahui pengaruh pemberian ROM pasif terhadap hemodinamika pada pasien post operasi. Menggunakan metode kuantitatif dengan de sain penelitian quasi experimen. Teknik sampel dengan simple random sampling sebanyak 44 re spond en. Instrumen menggunakan alat tensimeter aneroid merek ABN, stetoskop, jam tangan, pulse oximetry dan lembar obsevasi. Analisis data dengan uji Wilcoxon. Jenis operasi yang paling banyak dilakuk an adalah URS sebanyak 12 (27,3\%). Jenis anestesi yang paling banyak digunakan adalah region anestesi sebanyak $41(93,2 \%)$. Hasil uji Wilcoxon sign rank didapatkan terdapat perbedaan pre dan post sistolik $\mathrm{p}<0,001$, diastolik $\mathrm{p}<0,001$, nadi $\mathrm{p}<0,001$, saturasi oksigen $\mathrm{p}<0,001$. MAP $\mathrm{p}<0,001$ serta peritaltik usus $\mathrm{p}<0,001$ setelah intervensi ROM pasif. Terdapat pengaruh pemberian ROM pasif terhadap nilai hemodinamika pasien post operasi. Pemberian ROM pasif sangat penting dalam menentukan nilai hemodinamika pasien post operasi.
\end{abstract}

Kata kunci: Hemodinamika, ROM Pasif, Peristaltik Usus

\begin{abstract}
Surgery causes changes in the continuity of body tissues. Hemodynamic assessment and treatment are essential parts of the patient. Knowing the effect of giving passive ROM on hemodynamics in postoperative patients. The study implemented a quantitative with quasi-experimental research designs. The sample was obtained from a simple random sampling of 44 respondents. An instrument used a tensimeter an aneroid brand abn, a stethoscope, watches, pulse oximetry and a obsevasi. Data analysis by test wilcoxon. The most common type of operation was URS or 12 (27.3\%). The most utilized type of anesthesia was the regional anesthesia or 41 (93.2\%). Wilcoxon sign rank test discovered that there were difference between pre and post systolic $p<0.001$, diastolic $p<0.001$, pulse $p<0.001$, oxygen saturation $p<0.001$. MAP $p<0.001$ and intestinal peritaltic $p<0.001$ after passive ROM intervention. There are effect of providing passive ROM on intestinal hemodynamic postoperative patients. The provision of passive ROM is very important in determining the hemodynamic values of postoperative patients.
\end{abstract}

Keywords: Hemodynamics, Passive ROM, Intestinal Peristalsis

\section{PENDAHULUAN}

Operasi merupakan salah satu tindakan yang dilakukan untuk mengatasi dan mengobati kondisi kesehatan pasien. Tindakan ini dilakukan karena penyakit yang dialami pasien sulit untuk diobati menggunakan obat-obatan ataupun terapi lainnya. Pada proses tindakannya pasien akan dilakukan anastesi dengan tujuan untuk mengurangi rasa nyeri saat dilakukan pembedahan (Kurniawan, 2018).

Corresponding author: 
Pemberian anestesi dapat dilakukan dengan inhalasi, parenteral maupun kombinasi, dimana setelah diberikan anastesi pasien akan merasa relaksasi dan hilangnya refleks maupun kesadaran (Smeltzer, 2013). Pemberian anestesi secara umum dapat mempengrauhi seluruh sistem fisiologi tubuh, paling utama adalah sistem saraf pusat dan pernapasan. Efek samping yang dialami pasien menghambat motilitas gastrointestinal serta muntah (Rehatta, 2019).

Laporan umum di Amerika mencatat kejadian kematian disebabkan operasi sebesar $0.2-0.6 \%$ di Amerika rata-rata $0,2-0,6 \%$ dan $0,03-0,1 \%$ disebabkan karena anastesi (Nainggolan, 2011). Pasien post operasi yang diberikan terapi obat sedasi dapat berpengaruh terhadap kesadaran yang akan menurunkan kemampuan secara aktif dan mempengaruhi sirkulasi darah maupun jantung (Zakiyyah, 2015). Monitoring hemodinamik pada pasien post operasi adalah bagian terpenting dalam menunjang kesehatan pasien. Komponen hemodinamik pada pasien terdiri dari tek an an darah, heart rate, indikator perfusi perifer, pernapasan, produksi urin, saturasi oksigen dan GCS (Jevon, 2009). Mobilisasi berkontribusi nilai saturasi oksigen pada pasien darurat. Saturasi oksigen pada pasien tersebut diberi mobilisasi dengan berbagai gerakan. Mobilisasi progresif tingkat I bisa mempertahankan nilai saturasi oksigen dalam pasien kritis dengan ventilator terpasang (Hartoyo, 2017).

Hasil penelitian Nopitasari (2015), menunjukkan adanya peningkatan sebesar 3,967 pada respirasi rate pre dan post intervensi ROM pasif. Hasil yang sama dalam penelitian Ningtyas et. al. (2017), yang meneliti tentang "Keefektifan mobilisasi level I dan II terhadap status hemodinamika resiko ulkus dekubitus di pasien kritis", diperoleh hasil ada perbedaan rata-rata tekanan darah, MAP, nadi dan skor Braden $(p<0,05)$. Selain mempengaruhi hemodinamika, tindakan anestesi dalam kegiatan operasi juga dapat berpengaruh terhadap peristaltik usus.

Pasien post operasi yang tidak mendapat mobilisasi dini dapat menyebabk an kekakuan sendi, dalam jangka panjang, proses penyembuhan luka akan semakin lama dan akan muncul luka baru akibat kurangnya mobilisasi. Selain itu, kurangnya mobilisasi akan mengganggu system pencernaan yang mana diakibatkan otot-otot pencernaan mengalami penurunan aktivitas. Pelaksanaan ROM pasif yang dilakukan perawat merupakan peran kolaboratif dengan fisioterapi yang disesuaikan dengan peraturan perundangundangan dan PPNI. Penelitian bertujuan mengetahui pengaruh pemberian ROM pasif terhadap hemodinamika pasien post operasi.

\section{METODE PENELITIAN}

Desain pada penelitian dengan quasi experimen dan rancangan "Pre and Post Test. Populasi adalah seluruh pasien setelah dilakukan operasi di ruang rawat inap RSUD Banyumas yang dilakukan pada bulan Desember tahun 2019 sebanyak 289 pasien. Teknik pengambilan responden menggunakan simple random sampling dengan jumlah sampel 44 responden. Instrumen yang digunakan dalam penelitian ini menggunakan alat tensimeter aneroid merek ABN, stetoskop, jam tangan, pulse oximetry dan lembar obsevasi yang dibuat peneliti sesuai dengan komponen penelitian. Analisis data dengan uji Wilcoxon.

\section{HASIL}

1. Karakteristik responden

Tabel 1

Distribusi Karakteristik Responden

\begin{tabular}{lcc}
\hline Variabel & n & \% \\
\hline Jenis kelamin & & \\
Laki-Laki & 22 & 50 \\
Perempuan & 22 & 50 \\
Usia & & \\
$17-25$ tahun & 4 & 9.1 \\
$26-35$ tahun & 12 & 27.3 \\
$36-45$ tahun & 11 & 25.0 \\
$46-55$ tahun & 12 & 27.3
\end{tabular}




\begin{tabular}{lcc} 
56-65 tahun & 5 & 11.4 \\
Pendidikan & & \\
SD & 6 & 13,6 \\
SMP & 21 & 47,8 \\
SMA & 15 & 34,1 \\
PT & 2 & 4,5 \\
Pekerjaan & & \\
Buruh & 8 & 18.2 \\
Pedagang & 8 & 18.2 \\
Petani & 6 & 13.6 \\
PNS & 2 & 4.5 \\
Swasta & 12 & 27.3 \\
Tidak Bekerja & 8 & 18.2 \\
Jenis Operasi & & \\
Biopsi & 1 & 2.3 \\
Debridemen & 5 & 11.4 \\
Eksisi & 8 & 18.2 \\
Hernia & 2 & 4.5 \\
HIS VAG & 2 & 4.5 \\
Insisi & 1 & 2.3 \\
Litotripsi & 1 & 2.3 \\
Sectia cesarea & 7 & 15.9 \\
TURP & 5 & 11.4 \\
URS & 12 & 27.3 \\
Jenis Anestesi & & \\
Regional & 44 & 100 \\
\hline
\end{tabular}

Tabel 1 didapatkan bahwa jenis kela min responden yang sama yaitu laki-laki dan perempuan sebanyak 22 (50\%). Usia pasien sebagian besar berusia antara 26-35 tahun $\mathrm{d}$ an 46-55 tahun sebanyak masing-masing 12 responden $(27,3 \%)$. Pendidikan y ang dimiliki responden sebagian besar adalah SMP sebanyak
$21(47,8 \%)$. Pekerjaan sebagian besar bekerja secara swasta sebanyak 12 responden $(27,3 \%)$. Jenis operasi yang paling banyak dilakukan adalah URS sebanyak 12 (27,3\%). Dan jenis anestesi yang paling banyak digunakan adalah region anestesi sebanyak $41(93,2 \%)$.

2. Rerata nilai hemodinamika dan peristaltik usus pasien post operasi

\section{Tabel 2}

\begin{tabular}{lcccc} 
Rerata Nilai Hemodinamika Dan Peristaltik Usus Pada Pasien Post Operasi \\
\cline { 2 - 5 } \multicolumn{1}{c}{ Variabel } & Mean & SD & Mean & SD \\
\hline Tekanan darah sistolik & 106,36 & 6,135 & 122,20 & 11,365 \\
Tekanan darah diastolic & 65,45 & 6,271 & 75,08 & 4,954 \\
Nadi & 79,16 & 3,285 & 82,39 & 4,340 \\
Saturasioksigen & 90,59 & 2,138 & 95,76 & 1,469 \\
MAP & 78,72 & 5,8403 & 90,68 & 8,6770 \\
Peristaltik usus & 3,32 & 0,983 & 13,02 & 1,6081 \\
\hline
\end{tabular}

Berdasarkan tabel 2 dapat dijelaskan bahwa didapatkan perbedaan nilai mean tekanan darah sistolik pre test-post test sebe sar $15,84 \mathrm{mmHg}$, perbedaan nilai mean tekanan diastolik sebesar 9,63 , perbedaan nilai mean pre test-post test sebesar 3,23 , perbedaan nilai mean saturasi oksigen pre test-post test sebesar 5,17, perbedaan nilai mean MAP sebesar 11,96, d an perbedaan nilai mean peristaltik usus pre testpost test sebesar 9,7 .

3. Pengaruh pemberian ROM pasif terhadap hemodinamika dan peristaltik usus pada pasien post operasi 
Tabel 3

Rerata Peringkat Selisih Nilai Hemodinamik Dan Peristaltik Usus

\begin{tabular}{|c|c|c|c|}
\hline Selisih tekanan darah & Peringkat & $\mathbf{N}$ & Rerata peringkat \\
\hline \multirow{3}{*}{$\begin{array}{l}\text { Tekanan darah sistolik } \\
\text { post test dan pre test }\end{array}$} & Negatif & 2 & 2.00 \\
\hline & Positif & 37 & 20.97 \\
\hline & Sama dengan & 5 & \\
\hline \multirow{3}{*}{$\begin{array}{l}\text { Tekanan darah diastolik } \\
\text { post test dan pre test }\end{array}$} & Negatif & 4 & 5.75 \\
\hline & Positif & 36 & 22.14 \\
\hline & Sama dengan & 4 & \\
\hline \multirow[t]{3}{*}{ Nadi post test dan pre test } & Negatif & 5 & 17.40 \\
\hline & Positif & 38 & 22.61 \\
\hline & Sama dengan & 1 & \\
\hline \multirow{3}{*}{$\begin{array}{l}\text { Saturasi oksigen post test } \\
\text { dan pre test }\end{array}$} & Negatif & 2 & 1.75 \\
\hline & Positif & 41 & 22.99 \\
\hline & Sama dengan & 1 & \\
\hline \multirow[t]{3}{*}{ MAP post test dan pre test } & Negatif & 2 & 10.00 \\
\hline & Positif & 37 & 20.54 \\
\hline & Sama dengan & 5 & \\
\hline \multirow{3}{*}{$\begin{array}{l}\text { Peristaltik usus post test } \\
\text { dan pre test }\end{array}$} & Negatif & 0 & .00 \\
\hline & Positif & 44 & 22.50 \\
\hline & Sama dengan & 0 & \\
\hline
\end{tabular}

Tabel 3 diperoleh hasil bahwa uji Wilcoxon sign rank didapatkan untuk selisih tekanan darah sistolik post dan pretest untuk peringkat negatif $T=2$ rerata $T=2$ dan peringkat positif $T_{+}=37$ rerata $T=20,97$. Sedangkan untuk selisih tekanan darah diastolik post dan pretest untuk peringkat negatif $T-=4$ rerata $T=5,75$ dan peringkat positif $T_{+}=36$ rerata $T=22,14$.

Hasil uji Wilcoxon sign rank didapatkan untuk selisih nadi post dan pre test untuk peringkat negatif $T=5$ rerata $T=17,4$ dan peringkat positif $T_{+}=38$ rerata $T=22,61$.
Sedangkan untuk selisih saturasi oksigen post dan pre test untuk peringkat negatif $T-=2$ rerata $T=1,75$ dan peringkat positif $T_{+}=41$ rerata $T=22,99$

Hasil uji Wilcoxon sign rank didapatkan untuk selisih MAP post dan pre test untuk peringkat negatif $T=2$ rerata $T=10$ dan peringkat positif $T_{+}=37$ rerata $T=20,54$. Sedangkan untuk selisih peristaltik usus post dan pre test untuk peringkat negatif $T-=0$ rerata $T=0$ dan peringkat positif $T_{+}=44$ rerata $T=22,50$

\section{Tabel 4}

Perbedaan Nilai Hemodinamika Dan Peristaltik Usus

\begin{tabular}{lccc}
\hline \multicolumn{1}{c}{ Variabel } & $\mathbf{Z}$ & $\mathbf{p}$ & $\mathbf{r}^{*}$ \\
\hline Perbedaan post dan pre tekanan darah sistolik & -5.393 & 0,001 & $-0,81$ \\
Perbedaan post dan pre tekana darah diastolik & -5.223 & 0,001 & $-0,78$ \\
Perbedaan post dan pre nadi & -4.663 & 0,001 & $-0,70$ \\
Perbedaan post dan pre satura si oksigen & -5.674 & 0,001 & $-0,85$ \\
Perbedaan post dan pre MAP & -5.173 & 0,001 & $-0,77$ \\
Perbedaan post dan pre peristaltik usus & -5.781 & 0,001 & $-0,87$ \\
\hline
\end{tabular}

*keterangan: nilai r (effectsize) dihitung dengan rumus, $r=\frac{Z}{\sqrt{N}}$.

Tabel 4 menjelaskan bahwa uji Wilcoxon sign rank didapatkan ada perbedaan pada sistolik pre test $(M d n=100 \mathrm{mmHg})$ dan post test $(M d n=120 \mathrm{mmHg}), \mathrm{z}=-5,393, \mathrm{p}<0,001, \mathrm{r}=-$ 0,81 dan ada perbedaan tekanan darah diastolik pre test $(M d n=60 \mathrm{mmHg})$ dan post test $(M d n=$ $70 \mathrm{mmHg}), \mathrm{z}=-5,223, \mathrm{p}<0,001, \mathrm{r}=-0,78$. Pemberian ROM pasif efektif terhadap peningkatan tekanan darah sistolik dan diatolik dengan pengaruh yang besar pada klien dengan post operasi.

Hasil uji Wilcoxon sign rank pada tabel 4 didapatkan ada perbedaan yang signifikan pada nadi pretest $(M d n=79 \mathrm{x} /$ menit $)$ dan posttest $(M d n=82 \mathrm{x} /$ menit $), \mathrm{z}=-4,663, \mathrm{p}<0,001, \mathrm{r}=-$ 0,70 . Pemberian ROM pasif efektif terhadap 
peningkatan nadi dengan pengaruh yang sedang pada klien dengan post operasi.

Hasil uji Wilcoxon sign rank didapatkan ada perbedaan yang signifikan pada saturasi oksigen pre test $(M d n=90 \%)$ dan post test $(M d n=95 \%), \mathrm{z}=-5,674, \mathrm{p}<0,001, \mathrm{r}=-0,85$. Pemberian ROM pasif efektif terhadap peningkatan saturasi oksigen dengan pengaruh yang besar pada klien dengan post operasi.

Hasil uji Wilcoxon sign rank pada tabel 4 didapatkan ada perbedaan yang signifikan pad a MAP pretest $(M d n=78 \mathrm{mmHg})$ dan posttest $(M d n=90 \mathrm{mmHg}), \mathrm{z}=-5,173, \mathrm{p}<0,001, \mathrm{r}=-$ 0,77 . Pemberian ROM pasif efektif terhadap peningkatan MAP dengan pengaruh yang sedang pada klien dengan post operasi.

Berdasarkan tabel 4 dapat dijelaskan bahwa hasil uji Wilcoxon sign rank didapatk an ada perbedaan yang signifikan pada peristaltik usus pretest $(M d n=3 \mathrm{x} /$ menit $)$ dan posttest $(M d n=13 \mathrm{x} /$ menit $), \mathrm{z}=-5,781, \mathrm{p}<0,001, \mathrm{r}=-$ 0,87 . Pemberian ROM pasif efektif terhadap peningkatan peristaltik usus dengan pengaruh yang besar pada klien dengan post operasi.

\section{PEMBAHASAN}

1. Karakteristik responden

Pasien sebagian besar berjenis kelamin adalah laki-laki sebanyak $22(55,0 \%)$. Hasil penelitian Irmawan \& Muflihatin (2017) menunjukkan bahwa pasien yang diberikan intervensi ROM sebagian besar laki-laki sebanyak $20(76.9 \%)$.

Usia responden paling banyak berusia antara 26-35 tahun dan 46-55 tahun sebanyak masing-masing 12 responden (27,3\%). Menurut Aritonang (2010) pasien yang berusia lebih tua memiliki koping yang lebih baik dibandingkan usia muda dalam mengatasi nyeri pada saat diberikan ROM. Penelitian Grace (2012), menjelaskan sebagian besar responden beru sia 20-34 tahun sebanyak 25 responden $(73,5 \%)$ melakukan mobilisasi dini post operasi seksio sesaria.

Pendidikan yang dimiliki responden sebagian besar adalah SMP sebanyak 21 (47,8\%). Mubarak (2009), menyatakan pendidikan memiliki pengaruh terhadap kemampuan seseorang dalam mengakses $d$ an menerima informasi kesehatan. Tinggi tingk at pendidikan seseorang akan mengiring tingginya tingkat pengetahuan seseorang sehingga kemampuan dalam menangkap informasi semakin baik.

Pekerjaan sebagian besar bekerja secara swasta sebanyak 12 responden $(27,3 \%)$. Pekerjaan memberikan peningkatan pengalaman kesehatan bagi individu sehingga mempercepat kesembuhan setelah tindakan operasi terutama yang menyangkut pekerjaannya (Setyono, 2014).

2. Pengaruh pemberian ROM pasif terh ad ap hemodinamika (tekanan darah) pada pasien post operasi

Hasil analisis diperoleh selisih tekanan darah sistolik post dan pre test untuk peringkat negatif $T-=2$ rerata $T=2$ dan peringkat positif $T_{+}=37$ rerata $T=20,97$. Sedangkan untuk selisih tekanan darah diastolik post dan pretest untuk peringkat negatif $T-=4$ rerata $T=5,75$ dan peringkat positif $T_{+}=36$ rerata $T=22,14$. Hasil uji Wilcoxon sign rank didapatkan ada perbedaan pada sistolik pretest $(M d n=100$ $\mathrm{mmHg})$ dan posttest $(M d n=120 \mathrm{mmHg}), \mathrm{z}=$ 5,393, $\mathrm{p}<0,001, \mathrm{r}=-0,81$ dan ada perbedaan tekanan darah diastolik pretest $(M d n=60$ $\mathrm{mmHg})$ dan post test $(M d n=70 \mathrm{mmHg}), \mathrm{z}=$ 5,223, $\mathrm{p}<0,001, \mathrm{r}=-0,78$. Pemberian ROM pasif efektif terhadap peningkatan tekanan darah sistolik dan diatolik dengan pengaruh yang besar pada klien dengan post operasi.

Hasil penelitian ini menunjukkan peningkatan hemodinamika pada tekanan sistolik sebesar 15,84 $\mathrm{mmHg}$ dan tekanan diastolik sebesar 9,63. Darah yang dipompa didalam jantung dalam satu detak jantung sebanyak $70 \mathrm{~mL}$ dari setiap ventrikel dalam keadaan istirahat dan posisi terlentang. Jumlah darah yang dipompa terjadi peningkatan menandakan adanya respon terhadap aktivitas simpatis, yang merupakan kontrol ekstrinsik stroke volume (Sherwood, 2011).

3. Pengaruh pemberian ROM pasif terh ad ap hemodinamika (nadi) pada pasien post operasi

Hasil penelitian menunjukkan bahwa untuk selisih nadi post dan pre test untuk peringkat negatif $T-=5$ rerata $T=17,4$ dan peringkat positif $T_{+}=38$ rerata $T=22,61$. Hasil uji Wilcoxon sign rank didapatkan ada perbedaan yang signifikan pada nadi pre test $(M d n=79 \mathrm{x} / \mathrm{menit})$ dan post test $(M d n=82$ $\mathrm{x} /$ menit $), \quad \mathrm{z}=-4,663, \mathrm{p}<0,001, \mathrm{r}=-0,70$. Pemberian ROM pasif efektif terhadap 
peningkatan nadi dengan pengaruh yang sedang pada klien dengan post operasi.

Pengukuran Heart rate dapat dilakukan di beberapa tempat meliputi: arteri temporal di sisi dahi, arteri wajah pada sudut rahang, arteri karotis pada leher, arteri brakialis, arteri radial di pergelangan tangan, arteri fermonalis di pangkal paha, arteri popliteal dibelakang lutut posterior tibialis, arteri dorsalis pedis pada arteri diatas kaki. Biasanya paling mudah untuk merasakan denyutan dari arteri pada bagian arteri radial dan arteri karotis (Medical Life Sciences, 2017).

Hasil penelitian ini menunjukkan peningkatan hemodinamika pada nadi sebesar 3,23. Jantung adalah organ yang ditentukan oleh kerja sistem saraf simpatis dan parasimpatis. Pelepasan norepinefrin dari post ganglionic saraf simpatis mengaktivasi 1adrenoreceptors di jantung, terutama di nodus sinoatrial, nodus atrioventrikular, jaringan konduktif His-Purkinje dan jaringan kontraktil atrium dan ventrikel. Stimulasi saraf simpatis meningkatkan denyut jantung (kronotropi), laju transmisi jaringan konduktif (dromotropi), dan kontraksi ventrikel (inotropi) (Ganong, 2013).

4. Pengaruh pemberian ROM pasif terh ad ap hemodinamika (saturasi) pada pasien post operasi

Hasil penelitian menunjukkan bahwa untuk selisih saturasi oksigen post dan pretest untuk peringkat negatif $T-2$ rerata $T=1,75$ dan peringkat positif $T_{+}=41$ rerata $T=22,99$. Hasil uji Wilcoxon sign rank didapatkan ada perbedaan yang signifikan pada saturasi oksigen pre test $(M d n=90 \%)$ dan post test $(M d n=95 \%), \mathrm{z}=-5,674, \mathrm{p}<0,001, \mathrm{r}=-0,85$. Pemberian ROM pasif efektif terhadap peningkatan saturasi oksigen dengan pengaruh yang besar pada klien dengan post operasi.

Hasil penelitian Nopitasari (2017), didapatkan adanya hubungan antara pemberian rom pasif terhadap pasien post craniotomy $p$ 0,000. Hasil ini menjelaskan adanya peningkatan hemodinamika pada saturasi oksigen sebesar 5,17. Saturasi oksigen adalah suatu gambaran presentasi hemoglobin dengan kandungan oksigen dalam pembuluh darah arteri. Setelah itu hemoglobin tersebut terdeoksigenasi atau telah terdistribusinya darah beroksigen dari arteri ke jaringan tubuh.
5. Pengaruh pemberian range of motion (ROM) pasif terhadap hemodinamika (MAP) pada pasien post operasi di ruang rawat inap RSUD Banyumas

Hasil penelitian menunjukkan bahwa untuk selisih MAP post dan pre test untuk peringkat negatif $T=2$ rerata $T=10$ dan peringkat positif $T_{+}=37$ rerata $T=20,54$. Hasil uji Wilcoxon sign rank didapatkan ada perbedaan yang signifikan pada MAP pre test $(M d n=78 \mathrm{mmHg})$ dan post test $(M d n=90$ $\mathrm{mmHg}), \quad \mathrm{z}=-5,173, \quad \mathrm{p} \quad<0,001, \quad \mathrm{r}=-0,77$. Pemberian ROM pasif efektif terhadap peningkatan MAP dengan pengaruh yang sedang pada klien dengan post operasi. Hasil penelitian ini menunjukkan peningkatan hemodinamika pada nilai MAP sebesar 11,96.

6. Pengaruh pemberian ROM pasif terh ad ap peristaltik usus pada pasien post operasi

Hasil penelitian menunjukkan bahwa untuk selisih peristaltik usus post dan pretest untuk peringkat negatif $T-=0$ rerata $T=0 \mathrm{~d}$ an peringkat positif $T_{+}=44$ rerata $T=22,50$. Hasil uji Wilcoxon sign rank didapatkan ada perbedaan yang signifikan pada peristaltik usu s pre test $(M d n=3 \mathrm{x} /$ menit $)$ dan post test $(M d n=$ $13 \mathrm{x} /$ menit $), \mathrm{z}=-5,781, \mathrm{p}<0,001, \mathrm{r}=-0,87$. Pemberian ROM pasif efektif terhadap peningkatan peristaltik usus dengan pengaruh yang besar pada klien dengan post operasi. Penelitian Prayitno (2011), diperoleh ambulasi dini memiliki pengaruh signifikan terhadap peningkatan peristaltik usus $\mathrm{p}=0,000$.

\section{KESIMPULAN}

Kesimpulan penelitian ini yaitu ada pengaruh pemberian ROM pasif terhadap hemodinamika (tekanan darah, nadi, MAP dan peristaltik) pada pasien post operasi di ICU RSUD Banyumas. Pemberian ROM pasif menentukan nilai hemodinamika pasien post operasi, dimana ROM pasif akan memperb aiki kondisi hemodinamika pasien.

Disarankan untuk Rumah Sakit, memberikan sosialisasi terhadap perawat tentang SOP dalam pelaksanaan mobilisasi dini post operasi sehingga dalam pelaksanaannya dapat terlaksana dengan baik. Penelitian ini diharapkan dapat dilakukan penelitian oleh peneliti berikutnya dengan variabel dan metode yang berbeda. 
DAFTAR PUSTAKA

Brunner \& Suddarth. (2013). Buku Ajar Keperawatan Medikal Bedah Edisi 8 Jilid 2. Jakarta: EGC.

Ganong, W. F. (2013). Fisiologi Kedokteran. Jakarta : EGC.

Hartoyo. (2017). Pengaruh Mobilisasi Progresif Level I Terhadap Tekanan Darah Dan Saturasi Oksigen Pasien Kritis Dengan Penurunan Kesadaran. Jurnal Perawat Indonesia, 1 (1).

Jevon, P. (2010). Basic Guide to Medical Emergencies in the Dental Practice. Inggris: Wiley Blackwell

Kurniawan. (2018). Pengetahuan Pasien Pre Operasi Dalam Persiapan Pembedahan. Jurnal Penelitian Keperawatan, 2 (4).

Nainggolan, I. B. (2011). Peran perawat dalam upaya pencegahan komplikasi anestesi di Rumah Sakit Umum Pusat Haji Adam Malik. Medan. Jurnal.
Diunduh

melalui www.repository.usu.ac.id

Nopitasari. (2017). Pengaruh ROM Pasif Terhadap Laju Pernapasan Dan Spo2 Pada Pasien Post Craniotomy di ICU RSUD dr. Moewardi Surakarta Tahun 2015. Jurnal Keperawatan Global, 2 (2).

Prayitno J. (2011). Hubungan Ambulasi Dini Terhadap Aktivitas Peristaltik Usus Pada Pasien Post Operasi Fraktur Ekstremitas Bawah Dengan Anestesi Umum Di Ruang Mawar II RS Dr Moewardi Surakarta. Jurnal KesMaDaSka. 34-41.

Rehata. (2019). Anestesiologi Dan Terapi Intensif: Buku Teks Kati-Perdatin. Jakarta: Gramedia.

Sherwood, L. (2011). Fisiologi Manusia. Jakarta : EGC

Zakiyyah, A. (2015). Nyeri, Konsep dan Penatalaksanaan dalam Praktik keperawatan Berbasis Bukti. Jakarta: Salemb Medik 